\title{
Ethics of Global Citizenship in Education for Creating a Better World
}

\author{
Raouia Manseur \\ Department of Foreign Languages, University of Tlemcen, Tlemcen, Algeria
}

Email address:

roro91buzz@hotmail.com

\section{To cite this article:}

Raouia Manseur. Ethics of Global Citizenship in Education for Creating a Better World. American Journal of Applied Psychology. Vol. 6, No. 5, 2017, pp. 118-122. doi: 10.11648/j.ajap.20170605.16

Received: June 23, 2017; Accepted: August 15, 2017; Published: October 23, 2017

\begin{abstract}
In a world that is full of dangerous and serious global issues, preserving human rights and keeping peace and stabilization seem to be very difficult. EFL (i.e., English as foreign language) teachers should be wary of the global issues in addition to the suspicious events, such as violence, inequality, injustice, disrespect and other negative aspects, which happen outside their classrooms. Henceforth, to avoid or at least reduce the effects of the global problems, they should provide instruction on the ethics of global citizenship to make their students cautious about what would be encountered outdoor since they are members belonging to the same society. The responsibility of teachers increases in this status quo, especially in terms of preparing their students to face the problems of the present epoch and equipping them with the skills and knowledge required to be citizens who know their rights and duties. The ethics of global citizenship have their potential value in education because they prepare learners to face the global issues and provide them with the necessary skills and ethical concepts, such as respect, empathy, cooperation and many other standards in order to create global ethical societies.
\end{abstract}

Keywords: Citizens, Ethical Concepts, Education, Human Rights, Global Citizenship, Peace and Stabilization, Standards

\section{Introduction}

The globalized world that is characterized by inequality, injustice and all forms of violence and intimidation is a need of some standards, which may reduce the social and political problems and bring back social equilibrium to communities worldwide. Ethics of global citizenship are the principles, which help citizens overcome these problems, building rapport with one another, maintaining peace and stability and realizing justice and equality among people from different cultures. Global citizenship is not only about keeping the positive aspects, such as justice and peace, but it is also about respecting all kinds of membership. This means valuing and esteeming people's backgrounds, differences and cultural belongings. A global citizen is someone who is committed to certain values, attitudes and behaviours.. This person is acquainted with the basic ethics required for a socially appropriate behaving and sustainable social relationships among the members of his/her community. In fact, a global citizen is defined as "someone who identifies with being part of an emerging world community and whose actions contribute to building this community's values and practices" [18].
Teaching the ethics of global citizenship has a preeminent role in educational contexts. It contributes to the development of the students' cognitive skills. For instance, through learning the ethics of global citizenship, a student would be able to critically think about the social situations and analyse issues related to real-life, in addition to identifying possible solutions creatively and innovatively [15].

\section{Ethicss}

Ethics is the moral values that control one's attitudes, behaviours and actions. It is the standards, which determine what is socially accepted and/or rejected. Ethics is the virtues that organise a particular society and guide its citizens. Angle (2004) presumes that ethics refer to the degree of respect that one shows in his/her behaviour. It is used as a judgement of proper behaviour. Respect is the core aspect of good and bad behaviour, which means the more one acts respectively, the more s/he sounds ethical [3]. Global citizenship is not given its importance although it may bring positive changes and ensure a stabilized society. It is observed that global citizenship is not given its real value, especially in education. 
"Global citizenship remained almost entirely absent from public debate" (p. 8) [13]. This may be due to people's unawareness of its importance and lack of knowledge in the arena of the global citizenship ethics. The first reason may be referred to the non-inclusion of the ethics of global citizenship in education as a means of guiding learners in their social life and organizing the relationship among citizens. There should be a clear difference to be considered between 'Ethic' and Ethics'. The former refers to the set of norms and standards, which imply how one should act and which guides the behaviours and decisions of a person or group of people, whereas the latter alludes to the systematic and sustained reflection on the nature of a morality or ethic. These reflections can be informal, such as the moral values and principles [7]. Ethics can be used to mean a plural noun when talking about the set of principles, values and standards that organize the relationships among people, while it can be used to allude to a singular one when referring to the study of these principles, values, standards and behaviours of the members of a particular society.

\section{Global Citizenship}

\subsection{What Is Meant by Global Citizenship}

As a concept, global citizenship has become popular in Europe and the Americas in government, civil society and educational discourses [2]. Citizenship is the membership, the fact of being related to a certain group that is determined by particular characteristics, such as age, gender, political affiliation and other features. However, global citizenship implies thinking for the whole world, having an intention of improving it and creating a sustainable environment. Basically, "the United Nations Secretary-General's Global Education First Initiative (GEFI) has established education as a means to foster global citizenship. To support this, UNESCO organised two landmarks meetings on GCE in 2013" [17]. Hashman et al. (2015) states that "global citizenship has been defined as requiring social responsibility, recognition of global interconnectedness, and an understanding of how global issues affect individual and community lives, how and why decisions are made which affect the planet and life on it, and most importantly, means by which the future can be influenced" (cited in Andrzejewski \& Alessio et al. 1999, p. 3). Thus, global citizenship means that one takes the responsibility of global matters related to his/her society. It concerns human rights and social justice. Oxfam (2012) argues that global citizenship is about understanding the need to tackle injustice and inequality, and having the desire and ability to work actively to do so. It is about "valuing the Earth as precious and unique, and safeguarding the future for those coming after us" (p. 37) [11]. Whereas, Schattle (2008) claims that "global citizenship has its origins in civic management, cultural immersion, or educational programs" (p. 21).

UNESCO defines global citizenship as "the sense of belonging to a broader community and common humanity. It emphasizes political, economic, social and cultural interdependency and interconnectedness between the local, the national and the global" (p.3) [14]. Global citizenship helps one to listen to others and share opinions respectively. Creating safe and fair environment can be realized through exposing leaners to an educational content, which reinforces the ethics of global citizenship. This means that global citizenship can be included within educational programs as a means to promote peace and stability in the society through teaching students what global citizen is and how to be so since the citizens who constitute the community are the ones who should be committed to the ethics of global citizenship in order to form an ethical globalized community. The most valuable principle of global citizenship is preserving human rights. This is due to the fact that global citizenship is against all types of violence, humiliation and unfairness. "Global citizenship education (GCE) is a framing paradigm which encapsulates how education can develop the knowledge, skills, values and attitudes learners need for securing world which is more just, peaceful, tolerant, inclusive, secure and sustainable" (p. 9) [17].

\subsection{What Is a Global Citizen}

The words citizenship and citizen usually refer to a national or regional identity. One who is recognized as a citizen of a particular nation has the special rights and duties prescribed by the government of that nation [12]. A global citizen is someone who:

a. Respects multiculturalism.

b. Realizes that unity and cooperation are the basic features of global citizens.

c. Is aware that his/her actions affect the world around him/her.

d. Behaves respectively, and acts in an empathetic way.

e. Has team-work spirit.

f. Helps other people and appreciates cooperation.

g. Takes the responsibility of global issues concerned with his/her society.

h. Knows his/her duties and rights very well.

i. Acts as an active member of the society for the sake of improving it.

j. Understands that all parts of the world are interconnected.

k. Behaves ethically in all situations.

\section{Global Citizenship Education}

Global citizenship is being embraced by educators, scholars, politicians and even business people [5]. It is required in education due to its importance and advantages, which may change the world into a better place. The present world is characterized by violence, inequality and injustice; therefore, global citizenship can bring change through the inclusion of its elements in the educational programs of schools and even universities. The aim of global citizenship education is equipping learners of different age categories with knowledge, values and skills, which reinforce instill respect for human 
rights, social justice, gender equality, diversity and environmental sustainability, in addition to empowering these learners to be responsible global citizens [14].

"Global citizenship is not an additional subject it is an ethos. It can best be implemented through a whole-school approach, involving everyone with a stake in educating children, from the children themselves to those with teaching and non-teaching roles in the school, parents, governors/school board members, and the wider community" (p. 2) [19]. Nonetheless, it is noticed that there is not much emphasis on global citizenship in educational institutions and academic areas. Graham Pike discusses how the idea of global citizenship was formed for at least a century and how various educational institutions and other arenas of education provided its content and characteristics. After that, Pike poses the question of why the concept of global citizenship is rarely used in education [1]. Citizenship education is based on the concept of helping young people, such as pupils and students to understand that they have rights and responsibilities and that their society works in a certain way in which they should play an active role. Education about citizenship will help learners to consider their worth and value as individuals, being unique citizens, differentiating between what is right and wrong, valuing difference and understanding that all people are different in many ways, take into account that one has duties and responsibilities as well as rights and understanding that one lives in a multicultural world where all people are equal [4].

"Urry's (1999) model of global citizenship looks beyond relying only on legal, nation-based constructions to instead rely upon the significance of one's culture, minority status, ecological footprint, consumerism, and mobility as ways for conceptualizing citizenship" [10]. Global citizenship education is transformative since it gives learners the competencies and opportunity to know their rights and obligations in order to form a better place and build a prosperous future. It is based on learning from other transformative education processes, particularly human rights education, education for inter-national/intercultural understanding, education for sustainable development and education for peace [13].

\subsection{How to Teach Global Citizenship}

The concept global citizenship in relation to education is used by educators in varied contexts in order to bring the world into their classrooms or send their learners to the world, so that they can be exposed to new content and various experiences [2]. Developing international communication can be achieved by engaging students in the global citizenship, and several materials, methods, approaches and activities can be used to teach global citizenship. For instance, videos can be useful to show how a global citizen behaves in his/her society and how the relationships can be maintained among globalized citizens. In the United States, a survey of social studies teachers revealed that $60 \%$ claimed that global citizenship is required for civics education [5]. Many universities introduce specific programs for the ethics of global citizenship, especially in USA; for example, they offer certificates in intercultural communication to promote the ethics of global citizenships. This is mainly because these programs help students to be more aware of the different global issues and be accustomed with the ethics of global citizenship.

Global citizenship education is deemed an ethos, the moral ideas and attitudes that belong to a particular group or society, it is not just a subject to be taught in educational contexts. UNESCO in cooperation with many experts worldwide identified the key conceptual dimensions of global citizenship. These dimensions, which learners should be exposed to included the following : Cognitive skills (i.e., acquiring knowledge and understanding and critically think about the global issues), socio-emotional skills (i.e., developing a sense of belonging to a common humanity and sharing responsibilities, rights and values), and behavioural skills (i.e., responsibly and effectively acting at local, national and international levels for a peaceful world) [16]. In other terms, global citizenship education can be used as a holistic approach to reduce the negative global issues, such as injustice, victimization, harassment and many other features.

Global citizenship can be reflected in the way one relates to people around him/her: "it is as much to do with how visitors are welcomed as it is about what and how teachers teach". This is because global citizenship in schools is based on the following principles:

a. The importance of reaffirming or developing a sense of identity and self-esteem

b. Valuing all pupils and addressing inequality within and outside school

c. Acknowledging the importance of relevant values, attitudes, and personal and social education

d. Willingness to learn from the experiences of others around the world

e. Relevance to young people's interests and needs

f. Supporting and increasing young people's motivation to effect change

g. A holistic approach to Global Citizenship-that it should be an ethos permeating all areas of school life (Cited in Oxfam, 1997, p.2) [19].

Global citizenship should be closely related to the school curriculum and applied in all educational institutions, being as a subject to be taught to pupils and students. This can contribute to forming global citizens and developing the global citizenship skills. Thus, schools should be the first source of promoting global citizenship education worldwide. There should be a bridge, which relates schools to the outdoor environment.

\subsection{Some Aims of Global Citizenship Education}

Global citizenship education aims at:

a. Creating a better world that is based on considering and respecting others;

b. Listening carefully to one another;

c. Being understandable and avoiding misunderstanding;

d. Stabilizing the notion of fairness, diversity and peace; 
e. Appreciating solidarity;

f. Promoting responsibility;

\subsection{Some Possible Advantages of Global Citizenship Education}

In the future, EFL teachers would :

a. Promote the sense of partnership through mutual agreement and interdependence.

b. Develop the students' competencies, enable them to be active members of the society and engage them effectively in the world.

In the future, students would be:

a. Respectful citizens.

b. Collaborative and united members of the society.

More importantly, education will be improved because teachers would be wary of the world challenges that their students may encounter, and learners would be also aware of their responsibilities towards their environment, being good citizens whom first aim is creating a better world.

Global citizenship is meant to create a stable place in which everyone can live in peace, and the relationship among the citizens of a certain society can be based on respect, fairness and other positive aspects. It is claimed that "the adoption of ideas of global citizenship would help to make the world a better place in which to live" (p. 12) [7]. Therefore, global citizenship is the way to a stable and wellorganized societies worldwide. The concept of global citizenship can guide the citizens in terms of moral responsibilities and develop their sense of social duties. It can also involve them in their community through showing empathy, cooperation and assistance. Helping one another and contributing to the development of one's community is a fundamental component of global citizenship education.

\section{Global Citizenship Education and Cognitive Skills}

Global citizenship education can train the human brain to work faster in situations where it can be difficult to make a decision or react over a particular issue in an appropriate manner. Sometimes, one may commit mistakes, which can be due to the bad decision taken or the bad behavior shown under specific conditions. For instance, when one humiliates another person, treats him/her badly or make a misleading judgement on this person; what is the best way to react over these situations? Here, it comes the role of Global Citizenship Education programs. If one had been exposed to instruction related to the different global issues, which may be encountered in his/her daily life, s/he would be knowledgeable about the best way to react over the global issues, such as humiliation, injustice and other matters.

Global citizenship programs help students to develop some cognitive skills, such as critical thinking through enabling them to think clearly about what they are supposed to do in their daily life, especially when encountering a particular problem. The cognitive skills also help them to think systematically and creatively. This implies using a multiperspective approach, which involves different perspectives, dimensions, issues and angles, such as problem-solving skills and reasoning [8].

Further, global citizenship deals with how the cognitive abilities affect the social relationships. That is, developing a mental competence that allows one to behave more appropriately in different situations can preserve and strengthen the social links among people. Global citizenship education develops "a better understanding of how mental health impacts on an interconnected global society and a recognition of the global importance of tolerance and respect for an individual's human rights with respect to mental health issues" [6].

\section{Conclusion}

Global citizenship education can be used as a pedagogical approach to raise the students' awareness towards the global issues and how they can ethically deal with different problems they may encounter in their daily life. Global citizenship education implies providing students with instruction on various values and skills to create a better world, which characterized by peace, fairness, stability and other positive features. Imparting knowledge that is related to ethical virtues in educational institutions and academic areas, such as schools and universities can bring positive effect for both individuals and communities.

\section{References}

[1] Abdi, A. A. and Shultz, L. (Eds.). (2008). Educating for Human Rights and Global Citizenship. Retrieved from https://books.google.dz/books?id=MR7PeCZE9b0C\&printsep $=$ frontcover $\& \mathrm{dq}=$ global + citizenship $\& \mathrm{hl}=\mathrm{fr} \& \mathrm{sa}=\mathrm{X} \& \mathrm{ved}=0 \mathrm{aaa}$ hUKEw4pL5zMjUAhVIVxQKHY45AYsQ6AEITTAG\#v=on epage $\& \mathrm{q}=$ global $\% 20$ citizenship $\& \mathrm{f}=$ false

[2] Andreotti, O. V. and Souza T. M. M. L. (2012). Postcolonial Perspectives on Global Citizenship Education. UK: Routledge.

[3] Angle, C. (2004). Defining Ethics Good and Evil. Retrieved from https://books.google.dz/

books?id=Xa9gW7Ih6LIC\&printsec $=$ frontcover\&dq $=$ what + is +ethics\&hl=fr\&sa $=$ X\&ved=0ahUKEwih5p6zs7X

QAhWBkBQKHWqyDs8Q6AEIUTAH\# $\mathrm{v}=$ onepage $\& \mathrm{q}=$ what $\% 20$ is $\% 20$ ethics\&f=false

[4] Collins, M. (2008). Global Citizenship for Young Children. Retrieved from

https://books.google.dz/books?id=9YHDFR1 AhvoC\&printsec $=$ frontcover \&dq $=$ global + citizenship $\& \mathrm{hl}=\mathrm{fr} \& \mathrm{sa}=\mathrm{X} \& \mathrm{ved}=0 \mathrm{ahU}$ KEwiB4pL5zMjUAhVIVxQKHY45AYsQ6AEIPTAE\#v=one page $\& \mathrm{q}=$ global $\% 20$ citizenship $\& \mathrm{f}=$ false

[5] Dill, S. J. (2013). The Longings and Limits of Global Citizenship Education: The Moral Pedagogy of Schooling in a Cosmopolitan Age. Retrieved from https://books.google.dz/books?id= eodAAAAQBAJ\&printsec $=$ frontcover \&dq=global + citizenship + education $\& \mathrm{hl}=\mathrm{fr} \& \mathrm{sa}=\mathrm{X}$ \&ved=0ahUKEwiozrqHzcjUAhVBaxQKHW3-

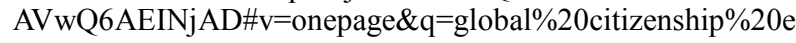
ducation $\& \mathrm{f}=$ false 
[6] Dillon, J. (2016). The Human Brain and Society. Module Overview. Retrieved from https://www.southampton.ac.uk/courses/modules/ uosm2016.page

[7] Dower, N. and Williams, J. (2002). Global Citizenship: A Critical Introduction. New York: Routledge.

[8] Global Citizenship Education. (2017). Retrieved from https://en.wikipedia.org/wiki/Global_citizenship_education

[9] Global Education Magazine. Global Citizenship Education. Retrieved June $21^{\text {st }}, 2017$ from $\mathrm{http}: / / w w w . g l o b a l e d u c a t i o n m a g a z i n e . c o m / g l o b a l-c i t i z e n s h i p-$ education/

[10] Harshman, J., Augustine, T. and Merryfield, M. (Eds) (2015). Research in Global Citizenhsip Education: AVolume in Research in Social Education. Retrieved from https://books.google.dz/books?id=dgYoDwAAQBAJ\&printsp $\mathrm{r}=$ frontcover\&dq=global+citizenship+in+education\&hl=fr\&sa $=$ X\&ved=0ahUKEwiQ6abRrs_UAhVKVRoKHTkrBJQQ6AE IPTAE\#v $=$ onepage $\& \mathrm{q}=$ global $\% 20$ citizenship $\% 20$ in $\% 20$ eeduc atio $\& \mathrm{f}=$ false

[11] McIntosh, M. (Eds.). (2013, March). Creating Culture of Global Citizens. Journal of Corporate Citizenship: Creating Global Citizens and Responsible Leaders. 2051- 4700 (49), 37. Retrieved from https://books.google.dz/books?id=01ODAAAQBAJ\&pg=PA37\&dq=global+citizenship+definition $\&$ hl=fr\&sa $=$ X\&ved $=0$ ahUKEwjuq8H5ubXQAhVHNxQKHX wxCc4Q6AEIQzAE\#v

$=$ onepage $\& \mathrm{q}=$ global $\% 20$ citizenship $\% 20$ definition $\& \mathrm{f}=$ false

[12] Noddings, N. (2005). Educating Citizens for Global Awareness. Retrieved from https://books.google.dz/books?id=8JR0W8AQp6oC\&printsec $=$ frontcover \&dq $=$ how + to + teach + global + citizenship $\& h l=f r \& s$ $\mathrm{a}=$ X\&ved=0ahUKEwjfs Yr3hNLUAhWCUhoKHRGCBr8Q6 AEIIDAA\# $\mathrm{v}=$ onepage $\& \mathrm{q}=$ how $\% 20$ to $\% 20$ teach $\% 20$ global $\% 2$ 0citizenship\& $\mathrm{f}=$ false

[13] Schattle, H. (2008). The practices of Global Citizenship. Retrieved from https://books.google.dz/books?id=En1AZSEn-
$\mathrm{nQC} \&$ printsec $=$ frontcover $\& \mathrm{dq}=\mathrm{global}+$ citizenship\& $\mathrm{hl}=\mathrm{fr} \& \mathrm{sa}$ $=$ X\&ved=0ahUKEwirh_PG0sPUAhXHthQKHX9oDKsQ6AE IIDAA

[14] Torres, A. C. (2017). Theoretical and Empirical Foundations of Critical Global Citizenship Education. Retrieved from https://books.google.dz/books?id=RCklDwAAQBAJ\&printse $\mathrm{c}=$ frontcover\&dq=global + citizenship + education $\& \mathrm{hl}=\mathrm{fr} \& \mathrm{sa}=\mathrm{X}$ \&ved $=0$ ahUKEwiozrqHzcjUAhVBaxQKHW3 AVwQ6AEITT $\mathrm{AG \# v}=$ onepage \&q$=$ global\%20 citizenship $\% 20$ education $\& \mathrm{f}=\mathrm{fa}$ lse

[15] UNESCO. (2014). Global Citizenship: Preparing Learners for the Challenges of the 21th century. Retrieved from http://unesdoc.unesco.org/images/0022/002277/227729E.pdf

[16] UNESCO. (2015). Global Citizenship Education: UNESCO's Approach. Retrieved from

https://www.google.dz/url?sa $=$ t\&rct $=\mathrm{j} \& \mathrm{q}=\&$ esrc $=\mathrm{s} \&$ source $=\mathrm{w}$ eb\&cd $=2 \& v e d=0$ ahUKEwjv3rWftc_UAhUBmxQKHdvbCU AhUBmxQK\&url=http\%3A\%2F\%2Fwww.unesco.org\%2FfFf ileadm $\% 2$ FMULTIMEDIA $\% 2$ FHQ $\% 2$ FED $\% 2$ Fpdf $\% 2$ FquFq uesti-answers-21jan-

EN.pdf\&usg=AFQjCNG7JcIKIExKcaGlRxBVnazOwwfFfQ

[17] United Nations Educational, Scientific and Cultural Organization. (2014). Global Citizenship Education: Preparing Learners for the Challenges of the $21^{\text {st }}$ century. Retrieved from https://books.google.dz/books?id=VvxnBAAAQBAJ\&pg=PA $42 \& \mathrm{dq}=$ global + citizenship + education $\& \mathrm{hl}=\mathrm{fr} \& \mathrm{sa}=\mathrm{X} \& \mathrm{ved}=0 \mathrm{ah}$ UKEwiozrqHzcjUAhVBaxQKHW3AVwQ6AEIYjAJ\#v=one page\&q=global\%20citizenship\%20education \&f=false

[18] What Does it Mean to Be a Global Citizen. (2013). Retrieved from https://www.opendemocracy.net/ourkingdom/ronisrael/what-does-it-mean-to-be-global-citizen

[19] Young, M. and Commins, E. (2002) Global Citizenship: The Handbook for Primary Teaching. Retrieved from https://books.google.dz/books?id=e56g8WJ9y1IC\&printsec=f rontcover\&dq $=$ global + citizenship \&hl $=$ fr $\&$ sa $=$ X\&ved $=0$ ahUK Ewirh_PG0sPUAhXHthQKHX9oDKsQ6AEIXjAI\#v=onepag $\mathrm{e} \& \mathrm{q}=\overline{\mathrm{global}} \% 20$ citizenship $\& \mathrm{f}=$ false 